\title{
Thrombosis service in The Netherlands
}

Citation for published version (APA):

Hemker, H. C. (1981). Thrombosis service in The Netherlands. International Journal of Cardiology, 1(2), 215-216. https://doi.org/10.1016/0167-5273(81)90035-8

Document status and date:

Published: 01/01/1981

DOI:

10.1016/0167-5273(81)90035-8

Document Version:

Publisher's PDF, also known as Version of record

\section{Please check the document version of this publication:}

- A submitted manuscript is the version of the article upon submission and before peer-review. There can be important differences between the submitted version and the official published version of record.

People interested in the research are advised to contact the author for the final version of the publication, or visit the DOI to the publisher's website.

- The final author version and the galley proof are versions of the publication after peer review.

- The final published version features the final layout of the paper including the volume, issue and page numbers.

Link to publication

\footnotetext{
General rights rights.

- You may freely distribute the URL identifying the publication in the public portal. please follow below link for the End User Agreement:

www.umlib.nl/taverne-license

Take down policy

If you believe that this document breaches copyright please contact us at:

repository@maastrichtuniversity.nl

providing details and we will investigate your claim.
}

Copyright and moral rights for the publications made accessible in the public portal are retained by the authors and/or other copyright owners and it is a condition of accessing publications that users recognise and abide by the legal requirements associated with these

- Users may download and print one copy of any publication from the public portal for the purpose of private study or research.

- You may not further distribute the material or use it for any profit-making activity or commercial gain

If the publication is distributed under the terms of Article $25 \mathrm{fa}$ of the Dutch Copyright Act, indicated by the "Taverne" license above, 


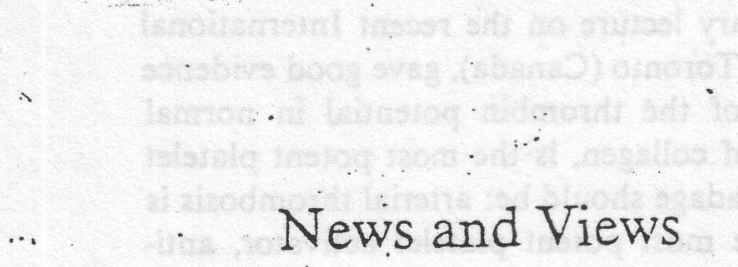

\author{
Thrombosis Service in The Netherlands
}

In July 1981 the Dutch Federation of Thrombosis Services held a congress on the occasion of its 10th anniversary. The Congress was devoted to a discussion of the recent ' 60 + trial' executed by Professor Loeliger and cow'orkers from Leiden University. This trial, the results of wich have been published with a discussion by Professor Mitchell, has attracted a certain amount of attention [1.2]. It demonstrated that constant deep anticoagulation after a first coronary infarction can indeed reduce the incidence of reinfarction. It seems as if the many negative trials reported did not obtain better results because constant deep anticoagulation could not be guaranteed.

The thrombosis services are non-profit organizations covering $95 \%$ of The Netherlands, where a team of nurses and a doctor supervise the anticoagulant therapy of patients referred to them by their cardiologists, other specialists or family doctors. At regular intervals the blood. level of vitamin $\mathrm{K}$ dependent clotting factors is assessed, and a dose of oral anticoagulants prescribed. Patients unable to come to the outpatient department are venipunctured at home. As up to $2 \%$ of the elderly population is on anticoagulant therapy, from one to several hundred patients are seen per day in each of the 70 thrombosis services in The Netherlands. Because the team of the thrombosis service uniquely specializes in this task, oral anticoagulation can be given with substantial intensity and still the bleeding risk is small (less than one major bleeding per 2000 treatment years). The minor bleedings that occur often appear to have a diagnostic meaning as they may be early signs of, for example a carcinoma. The Federation of Thrombosis Services has the task of coordinating the. different independent services, as to price charged to the insurance companies, quality of the laboratory estimations, etc.

Constant deep oral anticoagulation when properly administered can reduce reinfarction. This is of great practical importance, but it also is not without theoretical interest. The common ideas about arterial and venous thrombosis at the moment can be briefly summarized as follows. Venous thrombosis is primarily due to the clotting of blood; hence, oral anticoagulation will prevent it. Arterial thrombosis is mediated by platelets, and hence antiplatelet therapy is the attack of choice. Recent research from the Maastricht (Limburg, The Netherlands) research

The Editor encourages readers to contribute to this section of the Journal by sending aricles of no more than 1000 words on any topic of interest-clinical. scientific, educational, political, social or economic. 
group on thrombosis as presented at a plenary lecture on the recent International Congres's on Thrombosis and Haemostasis in Toronto (Canada), gave good evidence that thrombin at a concentration of $0.1 \%$ of the thrombin potential in normal plasma, in cooperation with small amounts of collagen, is the most potent platelet activator known. It may well be that the new adage should be: arterial thrombosis is mediated by platelets; since thrombin is the most potent platelet activator, anticoagulant therapy is the best antiplatelet therapy.

\section{References}

1 Loeliger EA. Roos J. Tijssen JGP. deVries WA. Anticoagulants after myocardial infarction. Lancet 1981: 1: 1321 .

2 Mitchell JRA. Anticoagulants in coronary hear disease-retrospect and prospect. Lancet 1981: 1: $257-262$.

H.C. Hemker*

Rijksuniversiteit Limburg Maastricht

- Member Editorial Board. International Journal of Cardiology. 